DOI: 10.30519/ahtr.519994

Advances in Hospitality and Tourism Research (AHTR)

\title{
TOURIST SATISFACTION: RELATIONSHIP ANALYSIS AMONG ITS ANTECEDENTS AND REVISIT INTENTION
}

\author{
Nirajan BAM ${ }^{1}$ \\ University of Northern Colorado, Greeley, USA \\ ORCID: 0000-0002-9350-6048 \\ Amrita KUNWAR \\ School of Business, Pokhara University, Nepal \\ ORCID: 0000-0002-8698-6733
}

\begin{abstract}
This study aims to investigate the factors affecting tourists' satisfaction and their revisit intention by randomly selecting 280 tourists from Pokhara, Nepal. Result of structural equation modeling confirmed the positive relationship between exogenous variables; hospitality service, the behavior of the people, and the cost of stay with tourist overall satisfaction. It further confirmed the significant positive association between tourist overall satisfaction and their intention to return. All the relations are statistically significant at the $5 \%$ level of significance. This study provides salient reference for future researcher, destination managers and policy makers of tourism industry of Nepal.
\end{abstract}

\section{Article History}

Received 31 January 2019

Revised 22 May 2019

Revised 19 August 2019

Accepted 20 August 2019

\section{Keywords}

tourist satisfaction

revisit intention

Pokhara

hospitality

structural equation modelling

\section{INTRODUCTION}

Positive association between tourist satisfaction and their intention to return (Dayour \& Adango, 2015) corroborates that satisfied tourist will either revisit the destination or share positive words about the destination. Some other studies agreed that when tourists' expectations are met, their

\footnotetext{
${ }^{1}$ Address correspondence to Nirajan Bam, Department of Applied Statistics and Research Methods, University of Northern Colorado, Greeley, USA. E-mail: bam6860@bears.unco.edu or nirajan@pu.edu.np
} 
likelihood of return to the same destination is higher (Chen \& Tsai, 2007). When consumers plan to travel, usually they recall the past memories to select the destination (Zhang et al., 2017, p. 326), therefore there are less likely chances that, unsatisfied traveler repeats the visit to same destination. Additionally, some other researchers in tourism and hospitality field also had similar thoughts in the past. They argued that, satisfaction of the tourists motivates them to return the same destination or recommend it to other people (Alegre \& Garau, 2010; Kozak, 2001b; Meleddu et al., 2015; Meng \& Han, 2018; Zhang et al., 2017). Past scholars' findings corroborate the fact that satisfaction of the tourist is one salient factor to motivate them to return or spread the positive words. This study aims to re-confirm this fact by selecting the sample of tourists who visited Pokhara, Nepal. It further purposed to explore the salient factors which are associated to tourist satisfaction.

Numerous scholar research papers have been found on topic of tourist satisfaction and its' consequences, but rarely have satisfaction and revisit intention of the tourists who visited Pokhara, Nepal been empirically investigated before. Therefore, aim of the study is to examine the overall satisfaction of the tourists, its determinant factors and consequences by selecting the sample of the tourists who visited Pokhara, Nepal at the time of survey. Similar studies have been conducted in some other parts of the world, but these studies do not truly represent the Nepalese tourist satisfaction and its impact on their revisit intention. Motivation and expectation of visitors are varying according to the location where they plan to visit. Pokhara, Nepal is one of the unique destinations for the tourists. Tourists who visit Pokhara expect something different from the tourists who visit other destinations in the world. Hospitality service, behavior of the local people and cost of the accommodation in Pokhara are different from other tourist sites of the world. Therefore, this study proposed to investigate the relationship between hospitality service, the behavior of the local people and cost of stay with tourist overall satisfaction, and it further aims to explore the relationship between tourist overall satisfaction and their revisit intentions. The empirical findings of this study provide the valuable reference background to destination managers, local government and policy makers to formulate development planning and marketing strategies to increase the arrival rate of tourists in Pokhara, Nepal. 


\section{LITERATURE REVIEW}

\section{Tourist Satisfaction and Revisit Intention}

Researchers in the past agreed that satisfaction is causing the tourist return to the same destination and sharing of positive word about the destination (Chen \& Tsai, 2007; Dayour \& Adongo, 2015; Kim et al., 2015). Dayour and Adango (2015) abstracted that motivation of the tourists is significant influencing factor of their intention to revisit, where overall satisfaction of the tourists plays the role of mediation. It also explored the fact that, satisfied tourist either revisits the related destination or shares positive word of mouth about the destination to other people. On the other hand, some other studies argued that overall satisfaction is not a primary cause of revisit intentions of the tourist. Um et al. (2006) abstracted that revisit intention has been regarded as an extension of satisfaction rather than an initiator of revisit decision-making process. This study revealed that perceived attractiveness, rather than overall satisfaction, is the most important indicator for future revisit intentions. Bigné et al. (2001) underlined that tourism image is antecedent of satisfaction, perceived quality, an intention to return and willingness to recommend to others, but there is no direct relationship between tourist satisfaction and their intention to return.

Even though, some scholars disagreed that satisfaction of the tourists is the strongest influential factor in their revisit intention (Bigné et al., 2001; Um et al., 2006), large mass of the researchers confirmed that overall satisfaction of the tourist is the primary influential factor for their revisit intention or recommendation to others (Alegre \& Garau, 2010; Chen \& Tsai, 2007; Kozak, 2001b; Meleddu et al., 2015; Meng \& Han, 2018; Zhang et al., 2017). Therefore, we proposed the following hypothesis for this study;

Hypothesis 1: The revisit intention of the tourists is positively related to their overall satisfaction.

Tourism researchers also viewed satisfaction and revisit intention through the lens of motivation theory. Some researches attempted to search for the answer to the question of why people travel and what are the factors that motivate them to travel. They agreed that there are two motivation forces, push and pull, that urge people to set travel decision. "Travelers are pushed into making a decision to travel by internal, psychological forces and pulled by the external forces of the destination attributes" (as cited in Yoon \& Uysal, 2005, p. 45). Pull motivations are those, tourists are influenced by the destination attractiveness, such as natural beauty, cultural 
attraction, recreation facilities etc. These destination attributes may encourage and reinforce inherent push motivation (Yoon \& Uysal, 2005, p. 45). This understanding supports the fact that if tourists are satisfied with the destination attributes like hospitality service, natural attraction, behavior of the people etc., it pulls them again towards the same destination. On the other hand, the internal forces are the ones that push them to revisit the related touristic place.

\section{Antecedents of Tourist Satisfaction}

Some researchers in the past confirmed that hospitality service quality is an antecedent variable of tourist satisfaction (Kim et al., 2013; Rimmington \& Yüksel, 1998; Ryu \& Han, 2010). Others viewed hospitality service quality as a part of general service quality (Chi \& Qu, 2008; Crompton, 1979; Kozak, 2001a; Meleddu et al., 2015; Pizam et al., 1978; Sam, 2009; Um et al., 2006; Yoon \& Uysal, 2005). In addition, researchers also investigated the relationship between food quality and customer satisfaction and found a significant positive association between them (Chi \& Qu, 2008; Kim et al., 2013; Sulek \& Hensley, 2004). Kim et al. (2013) found that perceived food healthiness increases the level of satisfaction, which, as a consequence; leads to customer's repeated visit in the future. Since food quality or food service is the part of hospitality service, it corroborates that hospitality service is salient influencing variable of tourist overall satisfaction too. Rimmington and Yüksel (1998) examined the relationship between tourist satisfaction and hospitality service quality, including some other variables and confirmed the positive relationship between hospitality service and tourist satisfaction. Nield et al. (2000) abstracted that food service is a salient factor which is responsible for tourists' satisfaction or dissatisfaction. Similarly, some researchers also stated that tourist loyalty comes from good service quality such as price quality, cleanliness, destination image, hospitality, accessibility, and tourist expectations which are all capped under tourist service quality (Ryu \& Han, 2010). These past studies provide enough background to set the following hypothesis;

Hypothesis 2: Tourist overall satisfaction and hospitality service are positively related.

Researcher of hospitality and tourism has also seen "cost of stay" as one of the salient determinant factors of tourist satisfaction. Price is one of the important influencing indicators of tourists' return intention (Kozak, 2001a). Travelers who feel that they paid a reasonable price for their 
expected service, are more likely to be satisfied than those who feel that they paid higher price (Hutchinson et al., 2009). Stevens (1992) highlighted that, price is less important than qualitative factors such as beautiful scenery, accommodation quality, and cultural programs, but it is more salient when tourists select the variety of other product related to the trip.

Some scholars of the marketing paradigm highlighted that price is one of the important factors of customer satisfaction (Ryu \& Han, 2010) and it is also the salient influencing factor of customer switching behavior (Keaveney, 1995). According to De Ruyter et al. (1997), customers may not necessarily buy the service of the highest quality level, but they may be satisfied with low perceived quality. In summary, these studies have seen the price as one of the salient influencing factors of customer satisfaction. Tourists are also a kind of customers for the tourist destination. Therefore, these studies corroborate the fact that, the price is one of the antecedent factors of tourist satisfaction. Following hypothesis is proposed for this study after reviewing the past studies;

Hypothesis 3: Tourist overall satisfaction is positively related to the cost of the stay.

Local people of the tourist destination area are viewed as brand ambassadors for tourism industry (Papadimitriou et al., 2018). Therefore, behavior of the local people is a salient influencing factor for the tourist satisfaction and their intention to revisit. Sheldon and Abenoja (2001) researched on residents' attitude in a mature destination and agreed that residents' attitude towards tourist is important for the sustainability of the tourism. In addition, host community support for tourism development is important, but it is affected by the level of concern, eccentric values, utilization of resource base, perceived costs, and benefits of tourism development (Gursoy et al., 2002). Furthermore, Braun et al. (2013) investigated the importance of local residents in place branding and concluded that local residences are a significant target group of place branding. To sum up, these studies support that the behavior of the local people is important for tourist satisfaction. Even though most of the researcher focused on the attitude of the local people and destination branding, rarely the researchers focused on the relationship between the behavior of the local people and tourist overall satisfaction and their revisit intention. Therefore, this study proposed to examine the relationship between the behavior of the local people and tourist overall satisfaction. Following hypothesis is proposed for this study; 
Hypothesis 4: There is a positive relationship between the behavior of the local people and tourist overall satisfaction.

Based on the proposed hypotheses, proposed conceptual model for this study is presented in the Figure 1.

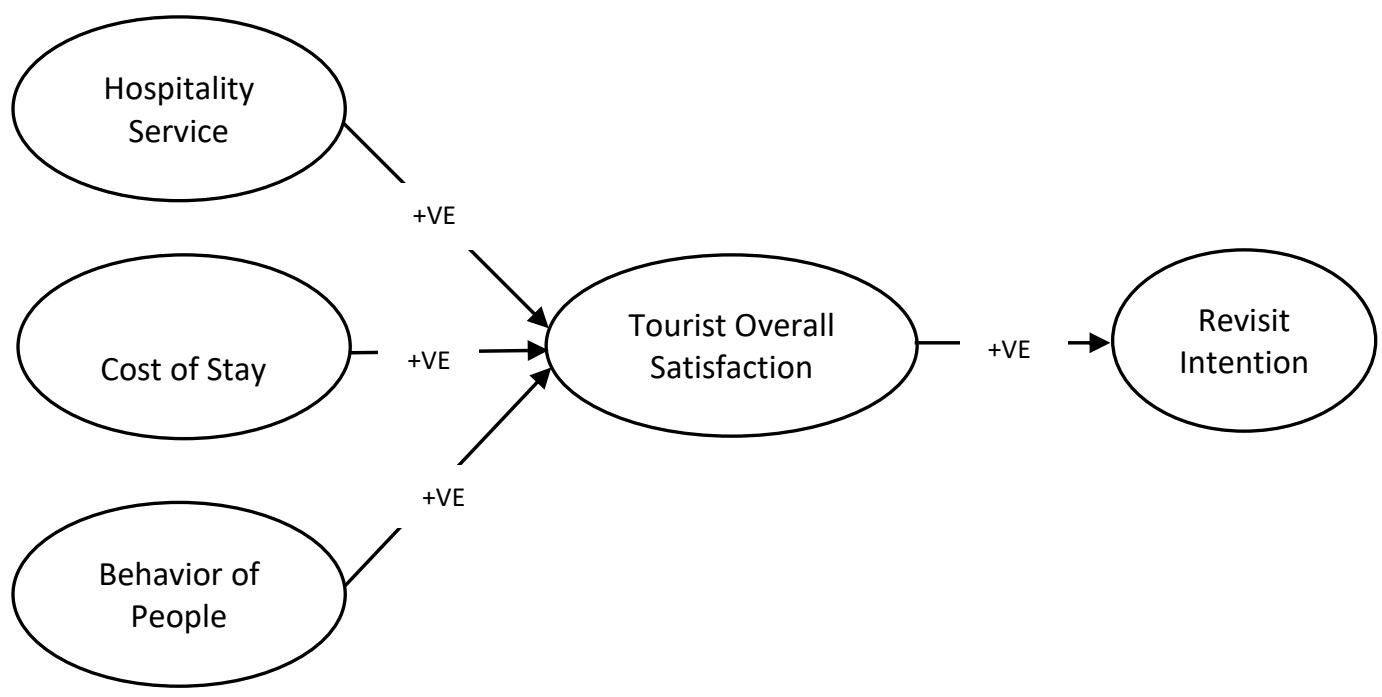

Figure 1. Conceptual Model

\section{METHODOLOGY}

\section{Study Instrument}

The self-administered questionnaire was used for this study. There are three parts of the questionnaire. In the first part participant tourists required to indicate their level of satisfaction about infrastructure condition, hospitality service, environmental condition and cost of stay, ranges from 1-5 (1= "very dissatisfied", 5= "very satisfied") and in part II participant tourists required to indicate their level of agreement about overall satisfaction and revisit intention ( $1=$ "strongly disagree", $5=$ "strongly agree"). The third part includes the participants' profile; gender, age, the frequency of visit, expenditure, tourist home country, length of stay. Pilot testing was conducted in order to assess the effectiveness of the questionnaires and to correct the erroneous items. Questionnaire was also translated into Chinese language for Chinese tourists, since pilot testing showed that Chinese tourists have difficulties in understanding English. Internal consistency of the items was examined by Cronbach's alpha(a). Alpha value of more than 0.7 was considered as a reliable variable. Composite reliability 
was also measured to support the alpha coefficient. Composite reliability coefficient of more than 0.6 was considered as reliable. Validity was examined by using the method of average variance extracted (AVE). AVE more than 0.5 was considered as valid. But, we accept AVE 0.4 or higher if the composite reliability is 0.6 or higher because if AVE is less than 0.5 but composite reliability is above 0.6 , convergent validity of the construct is still valid (Fornell \& Larcker, 2018). To test the goodness of fit the measurement model, structural equation modelling was adopted. Only fourteen items were significantly loaded under five constructs. All the factors are valid and reliable (see table 2). Therefore, this study is based on 14 valid and reliable items.

\section{Study Setting and Sampling}

Nepal is a beautiful Himalayan country. World largest peak Mount Everest, including world tenth largest peak the Mount Annapurna and other six mountains belong to Nepal. Pokhara, one of the beautiful tourist destinations of Nepal, is surrounded by beautiful lakes and a magnificent view of the Himalayan range of Mount Annapurna. It is located at the central part of the Nepal and connected via road transportation from all the border cities of Nepal. In addition, it is located at 20-minutes flight distance from capital city Kathmandu. Pokhara is the most popular tourist destination of Nepal, since in average it covers 35\% (approximately) of the total tourist population who visited Nepal in last ten years (Nepal tourism statistics, 2017).

Random sampling was adopted to select the participants for this study. 400 questionnaires were distributed to the tourists who visited Pokhara from August 2016 to April 2017 but only 280 respondents returned the questionnaire. Among them approximately $50 \%$ of respondents are male and $50 \%$ are female. $43 \%$ of the participants are Chinese, $38 \%$ are Indian and $19 \%$ are others. About $78 \%$ of the tourists are first-time visitors. The average length of stay of the tourist is 10 days after removing the outlier. The average length of stay of Chinese was 15.61 days, Indian was 4 days, and other was 8 days. Average per day expenditure of the tourist was US $\$ 40$ after removing outlier. Average per day expenditure of Chinese tourist was US $\$ 41.4$, Indian was US\$ 26 , and others was US\$83. Selfreported average satisfaction score, and intention to revisit score of Indian, Chinese, and others was more than 4 . 
Descriptive statistics such as mean, standard deviation, median, skewness, and kurtosis of the items as well as factors were extracted. Prior to run the structural equation modelling, principal component factor analysis was performed to eliminate the poorly loaded indicator items. Communalities of the indicator items and items below 0.6 were eliminated. Varimax rotation was adopted and factor loading of 0.40 was used as the benchmark of included items in a factor. SEM was adopted to know the association between proposed exogenous and endogenous variables. All data analysis was performed by using IBMSPSS 20, LISREL 8.54 and Excel 2016. Before performing the final analysis, descriptive statistics were explored. Skewness and kurtosis were examined to know the distribution nature of the extracted items.

\section{RESULTS}

Table 1 displays that mean of all the items is more than 3 and median of most of the items is 4 or more. It indicates that, tourists are satisfied and willing to revisit to the Pokhara again. Mean of items related to hospitality service lies between 3.62 to 3.84 and the median is 4 , which shows that tourists are satisfied with the hospitality service. Skewness and kurtosis of all the items related to hospitality service lie between the range of $+/-3$. Mean of items related to the behavior of the people range from 4.21 to 4.36 and median ranges from 4 to 5 , showing that tourists are highly satisfied with the behavior of the people. Skewness and kurtosis of all the items related to the behavior of the people lie between the range of $+/-3$.

Mean of price satisfaction ranging from 3.47 to 3.59 and median ranging from 3 to 4 , show tourists are moderately satisfied with the price structure. Skewness and kurtosis of all the items related to the cost of stay lie between the range of $+/-3$. Mean of overall satisfaction ranges from 4.11 to 4.99 and median ranges from 4 to 5 , it shows that there is high overall tourist satisfaction at Pokhara. Skewness and kurtosis of all the items related to overall satisfaction lie between the range of $+/-3$ except one item. Kurtosis of the item SAT4 is 3.17, it is not too far from the 3, therefore it is also reasonable to accept this item as normal. Mean of tourist revisit intention ranges from 3.6 to 4.19 and the median is 4 , it indicates that tourists are willing to revisit Pokhara again. Skewness and kurtosis of all the items of revisit intention lie between $+/-3$. All the indicator items are normal and no indication of normality violation. 
Table 1. Descriptive statistics

\begin{tabular}{|c|c|c|c|c|c|}
\hline Items & Mean & $\mathrm{SD}$ & Median & Skewness & Kurtosis \\
\hline Appealing accommodation facilities (HS1) & 3.84 & 0.9 & 4 & -0.69 & 0.49 \\
\hline Variety of food and beverage (HS2) & 3.71 & 0.95 & 4 & -0.43 & -0.27 \\
\hline Hygiene of food and beverage (HS3) & 3.62 & 1.01 & 4 & -0.31 & -0.59 \\
\hline Willingness to help customers (BL1) & 4.21 & 0.90 & 4 & -1.12 & -1.11 \\
\hline Warm and welcoming local people (BL2) & 4.36 & 0.88 & 5 & -1.53 & 2.28 \\
\hline Price of food and beverage (CC2) & 3.47 & 1.03 & 4 & -0.30 & -0.49 \\
\hline Price of local transportation (CC3) & 3.5 & 1.02 & 3 & -0.33 & -0.21 \\
\hline Price of products (CC4) & 3.59 & 0.97 & 4 & -0.68 & 0.33 \\
\hline It was a wise decision to visit Pokhara (SAT2) & 4.11 & 0.86 & 4 & -1.07 & 1.65 \\
\hline I had enjoyable time at Pokhara (SAT3) & 4.37 & 0.78 & 4 & -1.22 & 1.88 \\
\hline I am attracted by beautiful scenery of the & 4.99 & 0.82 & 5 & -1.7 & 3.17 \\
\hline \multicolumn{6}{|l|}{ Pokhara (SAT4) } \\
\hline $\begin{array}{l}\text { I am willing to return to Pokhara in the future } \\
\text { (RV1) }\end{array}$ & 4.19 & 0.86 & 4 & -1.12 & 1.42 \\
\hline $\begin{array}{l}\text { Pokhara will be my priority for future travel } \\
\text { (RV2) }\end{array}$ & 3.6 & 1.07 & 4 & -0.38 & -0.52 \\
\hline $\begin{array}{l}\text { I strongly recommend to my friends and } \\
\text { relatives to travel to Pokhara (RV3) }\end{array}$ & 4.12 & 0.95 & 4 & -1.06 & 0.99 \\
\hline
\end{tabular}

Prior to run the measurement model principal component factor analysis was performed to eliminate the poorly loaded indicator items. Table 2 shows that 14 items are loaded under 5 factors. Factor loading of all the items ranges from 0.64 to 0.86 , and $t$-values of each factor loadings are greater than 2 . Thus, all the factors are significant at $5 \%$. Average variance extracted (AVE) of all the factors fall above 0.4 and composite reliability of all the items fall above 0.6. Cronbach's alpha of all the factors ranges from 0.76 to 0.85 and overall Cronbach's alpha is 0.887 . It shows that all the items are reliable and valid. Fit indices of the measurement model also support that loading of the following 14 items in five latent variables; hospitality service (HS), behavior of the people (BL), cost of the stay (CC), overall satisfaction (SAT), and revisit intention (RV) are statistically significant, since $t$-values of all the path is more than 2 and fit indices are within the acceptable limit. Fit indices show that normalized chi square is $1.65(<3)$, RMSEA is $0.048(<0.08)$, GFI is $0.95(>0.9)$, RMR is $0.042(<0.05)$, NFI is 0.97 
$(>0.9)$ and CFI is $0.99(>0.9)$. It confirmed that the measurement model is valid and reliable.

Table 2. Measurement model results

\begin{tabular}{|c|c|c|c|c|c|c|c|}
\hline Constructs & Items & $\lambda$ & Error Variance & Cronbach's $\alpha$ & AVE & $\mathrm{CR}$ & $\mathrm{t}$ values \\
\hline \multirow[t]{3}{*}{ HS } & HS1 & 0.64 & 0.41 & & & & 12.84 \\
\hline & HS2 & 0.80 & 0.26 & 0.836 & 0.59 & 0.76 & 16.04 \\
\hline & HS3 & 0.85 & 0.3 & & & & 15.99 \\
\hline \multirow[t]{2}{*}{$\mathrm{BL}$} & BL1 & 0.74 & 0.27 & & & & 12.38 \\
\hline & BL2 & 0.67 & 0.34 & 0.76 & 0.50 & 0.62 & 12.34 \\
\hline \multirow[t]{3}{*}{$\mathrm{CC}$} & $\mathrm{CC} 2$ & 0.86 & 0.33 & & & & 15.84 \\
\hline & CC3 & 0.82 & 0.36 & 0.85 & 0.67 & 0.80 & 15.36 \\
\hline & $\mathrm{CC} 4$ & 0.78 & 0.34 & & & & 15.09 \\
\hline \multirow[t]{3}{*}{ SAT } & SAT2 & 0.65 & 0.31 & & & & 14.19 \\
\hline & SAT3 & 0.65 & 0.2 & 0.81 & 0.41 & 0.63 & 15.8 \\
\hline & SAT4 & 0.60 & 0.32 & & & & 13.43 \\
\hline \multirow[t]{3}{*}{ RV } & RV1 & 0.72 & 0.22 & & & & 16.65 \\
\hline & RV2 & 0.74 & 0.59 & 0.833 & 0.57 & 0.74 & 12.6 \\
\hline & RV3 & 0.81 & 0.24 & & & & 16.92 \\
\hline
\end{tabular}

Table 3 and equations 1, 2 and 3 shows the direction and magnitude of association between proposed exogenous and endogenous variables;

$\mathrm{SAT}=0.38^{*} \mathrm{HS}+0.43^{*} \mathrm{BL}+0.24^{*} \mathrm{CC}$, Error var. $=1.00, \mathrm{R}^{2}=0.42$

(3.76) (3.78) (2.58)

$\mathrm{RV}=1.28^{*} \mathrm{SAT}$, Error var. $=1.00, \mathrm{R}^{2}=0.74$

(7.55)

$\mathrm{RV}=0.49^{*} \mathrm{HS}+0.55^{*} \mathrm{BL}+0.30^{*} \mathrm{CC}$, Error var. $=2.64, \mathrm{R}^{2}=0.31$

(3.52) (3.60) 
Table 3. Results of path analysis

\begin{tabular}{|c|c|c|c|c|c|}
\hline $\begin{array}{l}\text { Exogenous } \\
\text { variable }\end{array}$ & Path & $\begin{array}{l}\text { Endogenous } \\
\text { variable }\end{array}$ & $\begin{array}{c}\text { Unstandardized } \\
\text { Estimate }\end{array}$ & $\begin{array}{c}\text { Standardized } \\
\text { Estimate } \\
\end{array}$ & $\mathrm{t}$ values \\
\hline $\begin{array}{l}\text { Hospitality } \\
\text { Service }\end{array}$ & & $\begin{array}{l}\text { Tourist Overall } \\
\text { Satisfaction }\end{array}$ & 0.38 & 0.29 & $3.76^{*}$ \\
\hline $\begin{array}{l}\text { Behavior of the } \\
\text { People }\end{array}$ & 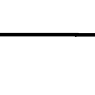 & $\begin{array}{l}\text { Tourist Overall } \\
\text { Satisfaction }\end{array}$ & 0.43 & 0.33 & $3.78^{*}$ \\
\hline Cost of Stay & & $\begin{array}{l}\text { Tourist Overall } \\
\text { Satisfaction }\end{array}$ & 0.24 & 0.18 & $2.58^{*}$ \\
\hline $\begin{array}{l}\text { Tourist Overall } \\
\text { Satisfaction }\end{array}$ & 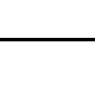 & Revisit Intention & 1.28 & 0.86 & $7.55^{*}$ \\
\hline \multicolumn{6}{|c|}{ Model Fit Statistics } \\
\hline Chi-Square & & 120.93 & & & \\
\hline Chi-Square/df & & 1.72 & & & \\
\hline RMSEA & & 0.051 & & & \\
\hline GFI & & 0.94 & & & \\
\hline RMR & & 0.038 & & & \\
\hline NFI & & 0.97 & & & \\
\hline CFI & & 0.99 & & & \\
\hline
\end{tabular}

* Significant at $5 \%$ level of significance

It shows that there is a significant positive relationship between hospitality service and tourist overall satisfaction since unstandardized beta coefficient is 0.34 and the standardized beta coefficient is $0.29(t=3.76)$. It supports hypothesis 2 . Likewise, there is a positive relationship between the behavior of the people and tourist overall satisfaction since unstandardized beta coefficient is 0.43 and the standardized beta coefficient is $0.33(t=3.78)$. It supports hypothesis 4 . Also, there is a significant positive relationship between the cost of stay and tourist overall satisfaction, where unstandardized beta coefficient is 0.24 and standardized beta coefficient is $0.18(\mathrm{t}=2.58)$. It supports hypothesis 3 . The overall coefficient of determination of the equation (1) is 0.42 , it shows hospitality service (HS), the behavior of the people (BL) and cost of stay (CS) accounts for $42 \%$ variation on the overall satisfaction of the tourist.

Equation 2 and table 3 shows, there is a significant positive relationship between overall tourist satisfaction and tourist revisit intention, since unstandardized beta coefficient is 1.28 and the standardized beta coefficient is $0.86(t=7.55)$. The coefficient of determination of equation 2 is 0.74 , it shows overall satisfaction of the tourist accounts for $74 \%$ variation on the tourist revisit intention. An equation (3) is the reduced structural equation, displayed direct relationship between revisit intention 
(RV) and other three variables of hospitality service (HS), behavior of the people (BL), and cost of stay (CC). Equation (3) shows that revisit intention (RV) has a significant positive relationship with hospitality service (HS), behavior of the people (BL), and cost of stay (CC).

All the proposed hypotheses are supported by the findings. The path analysis (table 3 ) confirms the proposed model. The model is a good fit since all the fit indices are within the cut-off value. $\chi 2 / \mathrm{df}$ is $1.72(<3), \mathrm{RMSEA}$ is $0.051(<0.08), \mathrm{GFI}$ is $0.94(>0.9), \mathrm{RMR}$ is $0.038(<0.05), \mathrm{NFI}$ is $0.97(>0.9)$ and CFI is $0.99(>0.9)$.

\section{DISCUSSIONS AND CONCLUSION}

Earlier studies have made a significant contribution to exploring the relationship of tourist satisfaction and their revisit intention, but tourists who visited Pokhara Nepal, were rarely the participants of these studies. Therefore, studies conducted in different part of the world might not reflect the satisfaction and revisit intention of those who visited Nepal. This study adds bricks to generalize the tourist satisfaction and revisit intention model by selecting tourists who visited Pokhara Nepal during the study period. Also, findings of this research could offer precious reference to destination managers and tourist planners in order to understand the importance of tourist satisfaction for motivation to revisit Pokhara.

Past studies consistently treat hospitality as a part of service quality (Chi \& Qu, 2008; Crompton, 1979; Meleddu et al., 2015; Pizam et al., 1978; Um et al., 2006; Yoon \& Uysal, 2005), but this study treated it as a separate antecedent factor of tourist overall satisfaction, as suggested by Rimmington \& Yüksel (1998). The study confirmed the positive association between hospitality and tourist satisfaction, in addition we found that most of the tourists are satisfied with the hospitality service. Our study strengthens the position of hospitality service as a salient antecedent variable of tourist satisfaction and their intention to return. Chinese and Indian foods along with Nepali cultural foods are available in Pokhara. Tourists could be satisfied with the variety of food and appealing accommodation facilities they received at Pokhara. They could enjoy their own preferred food with Nepali cultural food. Tourists are also satisfied with the hygiene of the food too. Because of appealing hospitality service offered by hotels in Pokhara, revisit of the tourists would be anticipated. 
Tourism studies in the past rarely treated behavior of the local people as an antecedent variable of tourists' overall satisfaction. However, Papadimitriou et al. (2018) critically evaluated behavior of the local residents as an influencing factor of word of mouth and destination branding. In the current study it was found that the behavior of the local people is a salient influencing factor of tourists' overall satisfaction and confirmed a significant positive association between them. Average score of this construct also shows that tourists are highly satisfied with the behavior of the people of Pokhara. Majority of the tourist destinations in Pokhara offers a welcome and cultural program for tourists. They could be kind and cooperative with tourists, which can make them feel good and satisfied with locals' behavior. If tourists are satisfied with behavior of the local people, it will definitely motivate them to revisit Pokhara. For the tourism development, local people should be kind and cooperative with tourist but be cautious if tourists are involving in some restricted activities, violating the government laws, harming the local community and environment etc. This study also adds value to the tourism literature by exploring the importance of the locals' behavior for tourist satisfaction and their revisit intention.

Cost of stay is another salient exogenous predictor variable of the tourist overall satisfaction. Researchers in the past also viewed cost as an important exogenous variable for tourist overall satisfaction. Kozak (2001a) concluded that level of price along with some other facilities such as hospitality service, customer care, entertainment etc. are important for revisit intention of tourists at the same destination. Hutchinson et al. (2009) highlighted that tourists who feel that they paid a reasonable price for their expected service, are more likely to be satisfied. Finding of the current study is similar to the one of Hutchinson et al. Finding of the current study also shows that tourists are moderately satisfied with the cost of stay at Pokhara and it is the weakest exogenous variable among all three of them. Less satisfaction of tourist in cost of stay at Pokhara could be because of two different price categories for air travel in Pokhara, and variation on the other accommodation prices for tourists (International tourist required to pay higher price than domestic tourists). Stevens (1992) viewed price as the less important factor than other qualitative factors such as beautiful scenery, quality of accommodation, and different cultures. But, he believes that price is important only when travelers select the other products related to travel. Authors of the current study have different stand point: if tourists are not satisfied with the price and if they feel they are paying more than their expected price level, they would feel they are cheated, which, consequently, 
will affect their satisfaction and intention to return. If tourists are unhappy with the price level, they would share the negative word of mouth, as a result, it will downsize the future tourist population. Therefore, cost of the stay is an important antecedent variable for the tourists' overall satisfaction and their revisit intention. Even though qualitative factors should have influence on the tourist overall satisfaction, as Stevens' (1992) thought, price is not less important factor either.

Result of positive association between tourists' overall satisfaction and their revisit intention corroborate the findings of the past studies where it was abstracted that satisfied tourists either return the same destination in the future or recommend it to other people (Alegre \& Garau, 2010; Chen \& Tsai, 2007; Kozak, 2001b; Meleddu et al., 2015; Meng \& Han, 2018; Zhang et al., 2017). Even though, high nobility seekers have less chances for visiting the same destination again (Bigné et al., 2001; Um et al., 2006), positive voice about the destination by pre-visitors motivate new nobility seekers to visit.

Current study confirmed that hospitality service, the behavior of the people and cost of stay through tourist overall satisfaction have significant influence on revisit intention of tourists. If tourists are not happy with hospitality service, cost of stay and behavior of the local people, there would be fewer chances of their revisit to the same destination, even though they are attracted by its beauty. Although current revisit trend of tourists shows that majority of them are first time visitors, self-reported score of the tourists shows that they are willing to revisit Pokhara. Survey results also show that tourists are less satisfied with the tariff rates of hotels, road transportation, and communication facilities (average self-reported score was less than 3.25). In case of climate and beautiful scenery of the Pokhara, tourists are highly satisfied (average self-reported score of climate and beauty was higher than 4). It is reasonable to claim that in the past visitors were moderately satisfied in Pokhara therefore, when they returned to their homes, they forgot about Pokhara and forget to share about it to their friends and relatives. Consequently, growth rate of the tourist in the recent years wasn't satisfactory. Tourist arrival rate would be increased by offering appealing hospitality service in minimum cost with pleasant behavior of the local people, improving the road transportation, and communication facilities, but destinations should be ready to accommodate the anticipated increased volume of tourists. Growth of the infrastructure development is salient to provide comfortable accommodation to the expected increased volume of the tourists for the sustainable tourism development. However, uncontrolled construction in the tourism site would hide the natural beauty 
and harm the environment, therefore, government as well as local community should be watchful about it.

Undoubtedly, higher tourist arrival rates would attract foreign investments which are important for the least developed countries like Nepal. Higher growth of the tourist arrivals has positive consequences for example; more jobs will be created by the expanded local and international tourism business in the tourist sites, large volume of local product will be sold in higher value and government revenue collection will increase. Along with focusing on the strategy to increase the tourist movements in the future, tourism managers of Pokhara should also focus on attracting more third country and Chinese tourists, since their per day expenditure and average length of stay is higher than Indians. For the sustainability of the tourism, government should; create the environment for the foreign investors, promote the expansion of local tourism business houses, and local community-based tourism businesses such as home stay. Role of the government should also be to educate the local communities about negative consequences of the tourism movements such as the destruction of environmental systems, and loss of cultural heritage. Government should also provide some decision-making role to local community in preserving the local cultural heritage and ecological system.

In conclusion, overall empirical results support all the proposed hypothesis. It corroborates that exogenous variables; hospitality service, the behavior of the people, and cost of stay have significant positive influence on tourist revisit intention through overall satisfaction. It is reasonable to conclude that satisfied tourists either return the same destination in the future or suggest it to other people. To increase the tourist arrival rates in the future, destination managers should offer appealing hospitality service in minimum cost with pleasant behavior without exploiting the ecological system and cultural heritage of the tourist sites.

This study would sketch the pathway for future researcher who wish to dig into the tourist satisfaction, its' influential factors and its' consequences, especially, for Nepalese tourism industry. It can work as a good reference for future academicians, researchers and graduate students. Finding of the study will also contribute to the tourism business managers, planners and government of Nepal to make a policy for the future tourism business.

Even though this study has significant contribution to the tourism literature in several ways and has several managerial implications, there are some limitations. First, the study area of the current study is Pokhara, city 
of Nepal. Therefore, call for future research to focus on other tourist destinations of Nepal is necessary. Although, the current instrument was tested for validity and reliability, some extensive research would be needed to strengthen the current measurement model. Only two items were loaded under the behavior of the people factor, therefore, in the future research more items can be included and tested for their validity and reliability. In addition, some other exogenous variables could be added to this model and have its' validity and reliability tested.

\section{ACKNOWLEDGEMENT}

This work was supported by the Pokhara University Research Council under faculty research grant [ FSY 2072-73].

\section{REFERENCES}

Alegre, J., \& Garau, J. (2010). Tourist satisfaction and dissatisfaction. Annals of Tourism Research, 37(1), 52-73. https://doi.org/10.1016/j.annals.2009.07.001

Bigné, J. E., Sánchez, M. I., \& Sánchez, J. (2001). Tourism image, evaluation variables and after purchase behavior: Inter-relationship. Tourism Management, 22(6), 607-616. https://doi.org/10.1016/S0261-5177(01)00035-8

Braun, E., Kavaratzis, M., \& Zenker, S. (2013). My city - my brand: The different roles of residents in place branding. Journal of Place Management and Development, 6(1), 1828. https://doi.org/10.1108/17538331311306087

Chen, C. F., \& Tsai, D. C. (2007). How destination image and evaluative factors affect behavioral intentions? Tourism Management, 28(4), 1115-1122. https://doi.org/10.1016/j.tourman.2006.07.007

Chi, C. G. Q., \& Qu, H. (2008). Examining the structural relationships of destination image, tourist satisfaction and destination loyalty: An integrated approach. Tourism Management, 29(4), 624-636. https://doi.org/10.1016/j.tourman.2007.06.007

Crompton, J. L. (1979). Motivations for pleasure vacation. Annals of Tourism Research, 6(4), 408-424. https://doi.org/10.1016/0160-7383(79)90004-5

Dayour, F., \& Adongo, C. A. (2015). Why they go there: International tourists' motivations and revisit intention to Northern Ghana. American Journal of Tourism Management, 4(1), 7-17. https://doi.org/10.5923/j.tourism.20150401.02

De Ruyter, K., Bloemer, J., \& Peeters, P. (1997). Merging service quality and service satisfaction: An empirical test of an integrative model. Journal of Economic Psychology, 18(4), 387-406. https://doi.org/10.1016/S0167-4870(97)00014-7

Fornell, C., \& Larcker, D. F. (2018). Evaluating structural equation models with unobservable variables and measurement error. American Marketing Association, 18(1), 39-50. https:// https://doi.org/10.2307/3151312

Gursoy, D., Jurowski, C., \& Uysal, M. (2002). Resident attitudes. Annals of Tourism Research, 29(1), 79-105. https://doi.org/10.1016/S0160-7383(01)00028-7 
Hutchinson, J., Lai, F., \& Wang, Y. (2009). Understanding the relationships of quality, value, equity, satisfaction, and behavioral intentions among golf travelers. Tourism Management, 30(2), 298-308. https://doi.org/10.1016/j.tourman.2008.07.010

Keaveney, S. M. (1995). Customer switching behavior in service industries: An exploratory study. Journal of Marketing, 59(2), 71-82. https://doi.org/10.2307/1252074

Kim, H. J., Park, J., Kim, M. J., \& Ryu, K. (2013). Does perceived restaurant food healthiness matter? Its influence on value, satisfaction and revisit intentions in restaurant operations in South Korea. International Journal of Hospitality Management, 33(1), 397-405. https://doi.org/10.1016/j.ijhm.2012.10.010

Kim, M. J., Jung, T., Kim, W. G., \& Fountoulaki, P. (2015). Factors affecting British revisit intention to Crete, Greece: High vs. low spending tourists. Tourism Geographies, 17(5), 815-841. https://doi.org/10.1080/14616688.2015.1062908

Kozak, M. (2001a). Comparative assessment of tourist satisfaction with destinations across two nationalities. Tourism Management, 22, 391-401.

Kozak, M. (2001b). Repeater's behavior at two distinct destinations. Annals of Tourism Research, 28(3), 784-807. https://doi.org/10.1016/S0160-7383(00)00078-5

Meleddu, M., Paci, R., \& Pulina, M. (2015). Repeated behavior and destination loyalty. Tourism Management, 50, 159-171. https://doi.org/10.1016/j.tourman.2015.01.032

Meng, B., \& Han, H. (2018). Working-holiday tourism attributes and satisfaction in forming word-of-mouth and revisit intentions: Impact of quantity and quality of intergroup contact. Journal of Destination Marketing and Management, (March), 1-11. https://doi.org/10.1016/j.jdmm.2018.03.009

Nepal tourism statistics (2017). Retrieved 15 October, 2019, from http://tourism.gov.np/files/statistics

Nield, K., Kozak, M., \& LeGrys, G. (2000). The role of food service in tourist satisfaction. International Journal of Hospitality Management, 19(4), 375-384. https://doi.org/10.1016/S0278-4319(00)00037-2

Papadimitriou, D., Kaplanidou, K. (Kiki), \& Apostolopoulou, A. (2018). Destination image components and word-of-mouth intentions in urban tourism: A multigroup approach. Journal of Hospitality and Tourism Research, 42(4), 503-527. https://doi.org/10.1177/1096348015584443

Pizam, A., Neumann, Y., \& Reichel, A. (1978). Dimensions of tourist satisfaction with a destination area. Annals of Tourism Research, 5(3), 314-322. https://doi.org/10.1016/0160-7383(78)90115-9

Rimmington, M., \& Yüksel, A. (1998). Tourist Satisfaction and food service experience: Results and implications of an empirical investigation. Anatolia, 9(1), 37-57. https://doi.org/10.1080/13032917.1998.9686958

Ryu, K., \& Han, H. (2010). Influence of the quality of food, service, and physical environment on customer satisfaction and behavioral intention in quick-casual restaurants: Moderating role of perceived price. Journal of Hospitality $\mathcal{E}$ Tourism Research, 34(3), 310-329. https://doi.org/10.1177/1096348009350624

Sam, H. S. (2009). The effect of motivation, past experience, perceived constraint, and attitude on tourist revisit intention. Journal of Travel Research, 48(1), 29-44.

Sheldon, P. J., \& Abenoja, T. (2001). Resident attitudes in a mature destination: The case of Waikiki. Tourism Management, 22(5), 435-443. https://doi.org/10.1016/S02615177(01)00009-7

Stevens, B. F. (1992). Price value perceptions of travelers. Journal of Travel Research, 31(2), 44-48. https://doi.org/10.1177/004728759203100208 
Sulek, J. M., \& Hensley, R. L. (2004). The relative importance of food, atmosphere, and fairness of wait: The case of a full-service restaurant. Cornell Hotel and Restaurant Administration Quarterly, https://doi.org/10.1177/0010880404265345

Um, S., Chon, K., \& Ro, Y. H. (2006). Antecedents of revisit intention. Annals of Tourism Research, 33(4), 1141-1158. https://doi.org/10.1016/j.annals.2006.06.003

Yoon, Y., \& Uysal, M. (2005). An examination of the effects of motivation and satisfaction on destination loyalty: A structural model. Tourism Management, 26(1), 45-56. https://doi.org/10.1016/j.tourman.2003.08.016

Zhang, H., Wu, Y., \& Buhalis, D. (2017). A model of perceived image, memorable tourism experiences and revisit intention. Journal of Destination Marketing and Management, (June), 1-11. https://doi.org/10.1016/j.jdmm.2017.06.004 